pastry products occupy a significant part, and constitute the dynamically developing segment. Therefore, our scientific interests were focused on the development of fat-containing culinary and confectionery products and choux pastry products. It was analytically confirmed that the realization of the process of choux pastry products manufacturing is mainly determined by technical and technological properties of the fat component. The fatty acid composition comparative analysis of traditional choux pastry fat ingredients (butter and margarine) and high oleic sunflower oil was conducted. The studies results of structurally-mechanical properties of choux pastry with high oleic sunflower oil and physicochemical indicators of baked semifinished products are provided in article. The plastic viscosity and other indicators of choux pastry deformation, depending on the oil and water content in a model system were determined. It was established that the optimal concentration of oil in the recipe is $32 \%$, the specific volume of baked semifinished product with this concentration is $7.3 \mathrm{~cm} 3 \mathrm{lg}$; the stability of shape is $1 \mathrm{s.u}$.; oven loss is 39\%; shrinkage is $4.4 \%$. Study of choux pastry fat recipe component properties in terms of technological process modeling will allow to manage and ensure the obtaining of competitive products with a balanced composition of nutritional and biological value. Keywords: high oleic sunflower oil, choux pastry semifinished products, structurally-mechanical properties, physicochemical indicators.

\title{
REFERENCES
}

1. Tsisarik O.J. fatty acid storage milk fat koriv / O.J. Tsisarik, G.V.Dronik // Biologiya tvarin. - 2008 - T10, №1-2. - S.84102.

2. O'Brien RD Fats and oils. Production, composition and properties and application. - 2007752.

3. Lisyuk GM Technology pastry and bakery products / GM Lisyuk // Confectionery - 2009. - №2. - S. 9-13.

4. Rumyantsev, VV Confectionery Technology: lecture notes for schools / VV Rumyantsev. - Orel: Orel State Technical University, 2009. $-141 \mathrm{p}$.

5. Pisarets OP Udoskonalennya tehnologï hlibobulochnih virobiv s vikoristannyam kukurudzyanogo Boroshnev: dis. cand. tehn. Sciences: 05.18.01 / Pisarets Olga Petrivna - Kyiv, 2015. - 196 p.

6. Machekhin. Rheometry food raw materials and products [Text]: Handbook / Ed. Machekhin. - M .: Agropromizdat, 1990. $271 p$.

7. Brewers PP Teoretichni Basics of nutritive tehnologiy: navch. posib. / PP .. Brewers AB Goralchuk., Je P. Brewers, [that in.] - X. HDUHT, 2010.-363 with.

Надійшла 13.09.2016. До друку 22.09.2016 Адреса для переписки: вул. Канатна, 112, м. Одеса, 65039

За матеріалами Міжнародної науково-практичної конференції «Харчові технології, хлібопродукти і комбікорми» (13-17 вересня 2016 р., ОНАХТ, м. Одеса)

ГУЛАВСЬКИЙ В.Т., канд. техн. наук заслужений працівник промисловості України, голова наглядової Ради ТОВ «Агросвіт»

\section{ПЕРСПЕКТИВИ СТВОРЕННЯ ДОААТКОВӦ̈ ВАРТОСТІ ПРИ ПЕРЕРОБЦІ ЗЕРНОВИХ КУЛЬТУР}

\section{1. Вступ}

Аграрний сектор України був і залишається одним із основних чинників економічної бази держави, а основою аграрного бізнесу є виробництво та переробка зернових культур.

Необхідно відзначити, що за останні 20..25 років виробництво зернових культур збільшується і динаміка є стійкою. Якщо в складі бувшого Радянського союзу Україна вирощувала в основному стабільно 44...46 млн.т зерна, то в минулому 20152016МР було вирощено біля 64 млн.т зерна 3 яких біля 40 млн. т було експортовано.

Вчені і практики в недалекому майбутньому прогнозують збільшення виробництва зернових культур до 80 млн. т, а також до 100 млн. т.

Цілком очевидним с факт, ще виробництво $\boldsymbol{i}$ переробка зернових культур в Украӥні має високі потенційні резерви.
Фактичне виробництво зерна та його перспективи цілком зрозумілі та очевидні тому розглянемо ситуацію, яка складається в галузі переробки, яка дає робочі місця і створює суттєву додану вартість.

Зрозуміло, що для переробки таких обсягів зерна, яке сьогодні вирощується, а також зважаючи на перспективу, необхідна сучасна, потужна, розгалужена переробна промисловість. Сюди потрібно віднести розвинуту логістичну інфраструктуру, маркетингову систему, інформаційну функцію та цілий ряд інших чинників.

Для більш точної характеристики ситуації, яка склалася в переробному секторі економіки України проаналізуємо дані по виробництву та використанню основних видів зернових культур за останні кілька років. 3 даних валового збору зернових культур та їх експорту за останні три роки ми бачимо дуже цікаві тенденції. Приведені дані показують, що пшениці, ячменю та сої ми експортуємо впевнено більше по- 
Валовий збір та експорт основних зернових культур в Украӥні

Таблиця 1 в 2014 - 2015роках та прогноз на 2016рік (тис. т.)

\begin{tabular}{|c|c|c|c|c|c|c|}
\hline \multirow[t]{2}{*}{ Культура } & \multicolumn{2}{|c|}{$2014 p$} & \multicolumn{2}{|c|}{$2015 p$} & \multicolumn{2}{|c|}{2016 (прогноз) } \\
\hline & "Валовий збір & $\overline{\text { Експорт }}$ & Валовий збір & $\overline{\text { Експорт }}$ & Валовий збір & 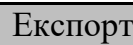 \\
\hline Пшшениця & 24113,97 & $\begin{array}{ll}10909,0 \\
\end{array}$ & 26531,95 & $\begin{array}{l}16938,0 \\
\end{array}$ & 25846,24 & 14600,0 \\
\hline Ячмінь & 9046,06 & 44464,0 & 8288,38 & 44412,0 & 99500,681 & $\overline{5000,0}$ \\
\hline "Кукурудза & 28496,81 & 19551,0 & 23327,57 & 16700,0 & 25754,03 & 17700,0 \\
\hline Овес & 612,46 & 38,0 & 488,51 & 43,0 & $\begin{array}{l}515,056 \\
\end{array}$ & $\overline{50,0}$ \\
\hline Соняшник & 10783,75 & 46,0 & 11751,12 & 90,0 & 13519,64 & 100,0 \\
\hline Соя & 3765,47 & 2419,0 & 3812,68 & 2300,0 & 3558,63 & 1915,0 \\
\hline Ріпак & 2154,06 & 1962,0 & 1798,56 & 181437,0 & 1483,33 & 1160,0 \\
\hline
\end{tabular}

Таблиця 2

Доля експорту основних зернових культур 3

Украӥни в 2014-2015роках та прогноз на 2016рік, \%

\begin{tabular}{||c||c||c|c||}
\hline \hline Культура & $\begin{array}{c}2014 \mathrm{p} \\
\% \\
\text { експорту }\end{array}$ & $\begin{array}{c}2015 \mathrm{p} \\
\% \\
\text { експорту }\end{array}$ & $\begin{array}{c}2016 \mathrm{p} \\
\text { \% експорту } \\
\text { (прогно3) }\end{array}$ \\
\hline \hline Пшениця & 45,24 & 63,84 & 56,49 \\
\hline \hline Ячмінь & 49,30 & 53,23 & 52,63 \\
\hline \hline Кукурудза & 68,61 & 71,59 & 68,73 \\
\hline \hline Соняшник & $\mathbf{0 , 4 3}$ & $\mathbf{0 , 7 7}$ & $\mathbf{0 , 7 4}$ \\
\hline \hline Соя & 64,20 & 60,30 & 53,80 \\
\hline \hline Ріпак & 91,10 & 79,90 & 78,20 \\
\hline
\end{tabular}

ловини вирощеного врожаю, а кукурудзи та ріпаку взагалі левову частку від вирощеного. I все це продається як сировина!

Але яким контрастом виділяється ситуація 3 насінням соняшнику - доля експорту стабільно менше одного відсотка. Все це завдяки тому, що в свій час олійно-жирове лоббі пробило закон на введення мита при експорті цієї культури. Створена правова ситуація стимулювала бурхливий розвиток олійноекстракційних заводів в результаті чого Україна посіла одне з передових місць у світі по експорту олійної продукції. Наша країна сьогодні по праву є світо-

вим лідером по виробництву та експорту соняшникової олії.

У виступах спеціалістів та керівників занятих в зерновому бізнесі часто $є$ теза про те, що нас ніхто не чекає на світових ринках з готовими продуктами, продавати їх дуже важко, від нас чекають тільки зерно. Абсолютно вірно, так дійсно говорять ті, кому потрібне зерно, хто хоче на ньому створити додаткову вартість і заробити капітал. Але це не вигідно тим, хто вирощує це зерно і не може використовувати в повній мірі його потенційні можливості.

А проблеми, які виникають при просуванні товарів на світових ринках, вони $є$ і будуть. Українська олія теж не легко завойовувала своє місце у світі. Двері відкривають тому хто в них стукає, так говорить народна мудрість.

Найбільш поширеними продуктами, які випускає на сьогодні, зернопереробна галузь є борошно, крупи та комбікорми. Яка ж ситуація складається 3 виробництвом та експортом цих продуктів в Україні видно з даних таблиці 3.

Якщо подивитися просто на цифри статистики, то ситуація виглядає слабкою, хоча тенденція показує ріст експорту. Але порівнюючи обсяги вирощування $з$ обсягами, які переробляє наша галузь, то результати просто вражають.

Таблиця 3

Виробництво та експорт борочна, круп і комбікормів в Украӥні в 2013, 2014, 2015 роках

\begin{tabular}{|c|c|c|c|c|c|c|c|c|c|}
\hline \multirow[t]{2}{*}{ Продукт } & \multicolumn{3}{|c|}{ 2013p (тис. т) } & \multicolumn{3}{|c|}{ 2014p (тис. т) } & \multicolumn{3}{|c|}{2015 р (тис. т) } \\
\hline & $\begin{array}{l}\text { Вироб- } \\
\text { ництво }\end{array}$ & $\overline{\text { Експорт }}$ & $\begin{array}{l}\text { \% екс- } \\
\text { порту }\end{array}$ & $\begin{array}{l}\text { Вироб- } \\
\text { ництво }\end{array}$ & $\overline{\text { Експорт }}$ & $\begin{array}{l}\text { \% екс- } \\
\text { порту }\end{array}$ & $\begin{array}{l}\text { Вироб- } \\
\text { ництво }\end{array}$ & Експорт & $\begin{array}{l}\text { \% екс- } \\
\text { порту }\end{array}$ \\
\hline "Борошно & 2400,0 & 229,8 & 9,6 & 2039,0 & 259,8 & 12,7 & 1980,0 & 344,2 & 1717,8 \\
\hline К Крупи & $\begin{array}{c}\text { Біля } \\
300 \\
\end{array}$ & 445,0 & 15,0 & $\begin{array}{c}\text { Біля } \\
300 \\
\end{array}$ & 60,5 & 20,2 & & & \\
\hline К Комбікорми & & 15,6 & & 6000,0 & & & $\begin{array}{l}\text { Біля } \\
7000\end{array}$ & & \\
\hline
\end{tabular}

Обсяги вирощування порівняно з обсягами переробки основних зернових культур.

\begin{tabular}{|c|c|c|c|c|c|c|}
\hline \multirow[b]{2}{*}{ Культура } & \multicolumn{3}{|c|}{ 2014p (тис.т) } & \multicolumn{3}{|c|}{$2015 p$ (тис.т) } \\
\hline & "Вирощено & Перероблено & \% \% переробки & 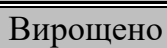 & Перероблено & \% \% переробки \\
\hline ППшениця & 24113,37 & "3200,0 & 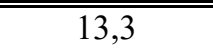 & 26531,95 & $\overline{2718,0}$ & 10,2 \\
\hline К Кукурудза & 28496,81 & 300,0 & (1,05 & 23327,57 & 300,0 & $1,1,3$ \\
\hline "Насіння соняшнику & 10783,75 & 10737,8 & 99,5 & 111751,12 & 111661,1 & 99,2 \\
\hline
\end{tabular}


На борошно в нашій країні переробляється $10 \ldots 13 \%$ зерна яке вирощується. Слід також зазначити, що парадокс заключається ще в тому, що незважаючи на такий малий відсоток переробки порівняно 3 валом, який вирощується, мукомели кожен рік відчувають гостру нестачу пшениці з необхідними показниками по клейковині та іiі якості. Це говорить про те, що в нашій країні повністю відсутня хоча би якась стратегія по раціональному використанню потенціалу пшениці.

Ще гірша картина в сфері вирощування круп'яних культур та виробництві круп. Тут щорічно великий дефіцит вирощування таких культур як гречиха, овес, просо і горох, що суттєво стримує як нарощування обсягів виробництва та експорту круп із них, так і розвиток самої індустрії. I навпаки використання обсягів виробництва кукурудзи на круп'яні вироби настільки низькі, що якщо всі вироблені крупи в Україні віднести на кукурудзу, то використання іiі ледь більше $1 \%$.

В галузі виробництва комбікормів ситуація має свої особливості. Якщо оцінювати обсяги виробництва, то вони в останні роки вийшли на рівень біля 8 млн. т. Обсяги виробництва комбікормів в Україні та їх асортимент тісно пов'язаний з потребами тваринництва нашої країни, що природно обмежує подальший розвиток цієї галузі. Розвиток експортного потенціалу цієї галузі стримує відсутність національного виробництва вітамінів, ферментів, амінокислот, преміксів та білкових компонентів. Залежність від імпорту цих складових суттєво впливає на собівартість комбікормової продукції, що не дає змоги формувати конкурентні переваги в ціновому сегменті при експорті.

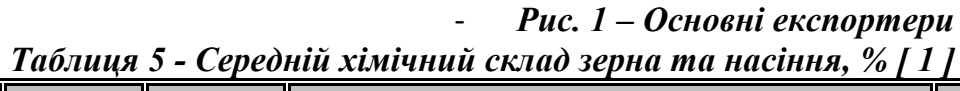

\begin{tabular}{|c|c|c|c|c|c|c|c|c|c|}
\hline \multirow[t]{2}{*}{ Культура } & \multirow[t]{2}{*}{ Вода } & \multirow[t]{2}{*}{$\overline{\text { Білки }}$} & \multirow[t]{2}{*}{ Жири } & \multicolumn{4}{|c|}{ в вуглеводи } & \multirow[b]{2}{*}{ Зола } & \multirow{2}{*}{$\begin{array}{c}\text { Енергетична } \\
\text { цінність } \\
(100 г), \text { ккал } \\
\end{array}$} \\
\hline & & & & Разом & $\begin{array}{l}\text { Моно- i } \\
\text { дисахариди }\end{array}$ & $\begin{array}{l}\text { Крох- } \\
\text { маль }\end{array}$ & $\begin{array}{l}\text { Кліт- } \\
\text { ковина }\end{array}$ & & \\
\hline $\begin{array}{l}\text { Пшениця } \\
\text { м'яка }\end{array}$ & 14,0 & 111,6 & 1,6 & 688,7 & 2,6 & $\overline{53,7}$ & 2,4 & 1,7 & 318 \\
\hline Жито & 14,0 & 9,9 & 1,6 & 70,9 & 3,5 & 54,0 & 1,9 & 1,7 & 320 \\
\hline Овес & 13,5 & 10,1 & 4,7 & $\overline{57,8}$ & 1,2 & 36,1 & 10,7 & 3,2 & 300 \\
\hline Ячмінь & 14,0 & 11,5 & 2,0 & 65,8 & 3,6 & $\overline{50,1}$ & 4,3 & 2,4 & 311 \\
\hline Просо & 13,5 & 11,2 & 3,8 & 60,7 & 2,5 & 54,7 & 7,9 & 2,9 & 307 \\
\hline Гречиха & 14,0 & 11,6 & 2,3 & 59,5 & 1,5 & 54,9 & 10,8 & 1,8 & 290 \\
\hline Рис & 14,0 & 7,3 & 2,0 & 63,1 & 3,1 & 55,2 & 9,0 & 4,6 & 284 \\
\hline Сорго & 13,5 & 11,1 & 3,3 & 66,4 & 1,6 & 56,0 & 3,5 & 2,2 & 323 \\
\hline Кукурудза & 14,0 & 10,3 & 4,9 & 67,5 & 2,7 & $\overline{56,9}$ & 2,1 & 1,2 & 338 \\
\hline \multicolumn{10}{|c|}{ Бобові } \\
\hline Горох & 14,0 & 23,0 & 1,2 & 53,3 & 4,2 & 46,5 & 5,7 & 2,8 & 303 \\
\hline Квасоля & 14,0 & 22,3 & 1,7 & 54,5 & 4,5 & 43,4 & 3,9 & 3,6 & 309 \\
\hline Соя & 12,0 & 34,9 & 17,3 & 26,5 & 9,0 & 2,5 & 4,3 & 5,0 & 395 \\
\hline \multicolumn{10}{|c|}{$\begin{array}{lll}\text { Олійні та ефіроолійні } \\
\end{array}$} \\
\hline $\begin{array}{l}\text { Насіння } \\
\text { соняшнику }\end{array}$ & $\overline{11,0}$ & 14,8 & 40,8 & 16,0 & 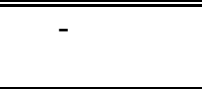 & 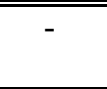 & 14,5 & 2,9 & 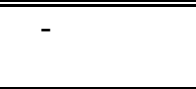 \\
\hline Льон & 8,0 & 24,1 & 48,6 & 11,1 & - & - & $4,4,4$ & 3,8 & - \\
\hline Клещевина & 7,0 & 18,3 & 51,3 & 2,0 & - & - & 18,6 & 2,8 & - \\
\hline Коріандр & 10,0 & 14,8 & 22,1 & 28,0 & - & - & 18,6 & 5,6 & - \\
\hline
\end{tabular}

Досить цікавою $є$ картина світового конкурентного середовища цих продуктів (рис. 1).

Підводячи підсумок по вищесказаному можна зробити наступні висновки:

- зернопереробна галузь для свого розвитку має потужну сировинну базу, яка також активно розвивається;

- розвиток виробництва зерна і розвиток переробної галузі не координується, що породжує відомі перекоси;

- розвиток зернопереробної галузі базується на застарілих технологіях, а розвиток інноваційних технологій не стимулюється державою;

- на світовий ринок поставляється продукція традиційного асортименту, що не робить ії конкуренто-привабливою;

- відсутність державного протекціонізму для продуктів зернопереробного комплексу України дає перевагу на цьому ринку країнам з меншими потенційними можливостями.

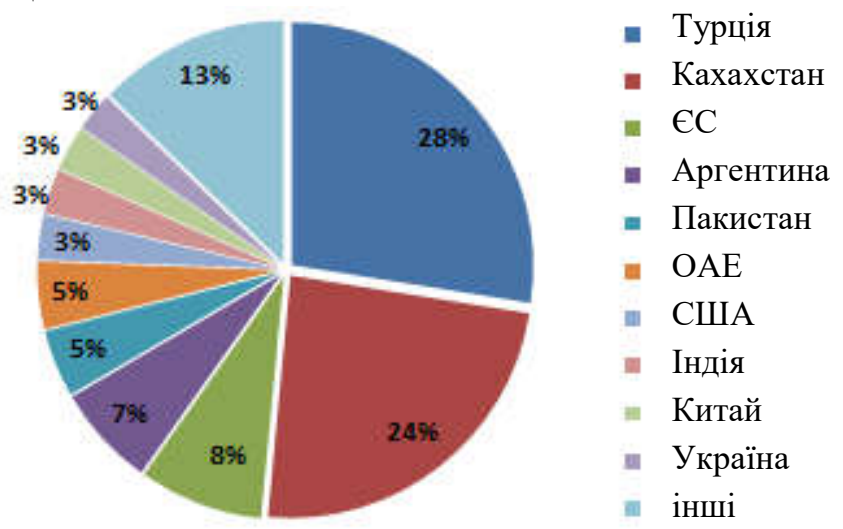

Рис. 1 - Основні експортери муки в світі 2014/15 МГ 
Таблиця 6

Фракційний склад білка борочна різного виду, \%

\begin{tabular}{|c|c|c|c|c|c|c|c|}
\hline \multirow{2}{*}{$\begin{array}{c}\text { Азот } \\
\text { фракційний }\end{array}$} & \multicolumn{7}{|c|}{ "Види борошна } \\
\hline & П Пшеничне & "Кукурудзяне & = Вівсяне & "Ячмінне & "Гречане & Рисове & Tритикалеве \\
\hline $\begin{array}{l}\text { Альбуміни і } \\
\text { глобуліни }\end{array}$ & 12,30 & $9,9,58$ & 10,20 & 24,57 & 39,85 & 18,62 & 31,11 \\
\hline Проламіни & 40,99 & 35,43 & 9,85 & 34,46 & 1,14 & $4,3,31$ & 33,34 \\
\hline Гллутеліни & "241,61 & 23,45 & "49,28 & 27,29 & "13,61 & $\begin{array}{l}54,60 \\
\end{array}$ & 2121,16 \\
\hline $\begin{array}{l}\text { Нерозчинний } \\
\text { залишок }\end{array}$ & 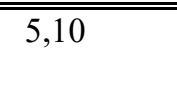 & 31,54 & 30,67 & $\overline{13,68}$ & $4 \overline{45,40}$ & 22,47 & 14,39 \\
\hline
\end{tabular}

Аналізуючи висновки ми можемо констатувати, що зернопереробна галузь України маючи непоганий потенціал знаходиться в досить складній ситуації. 3 цієї ситуації необхідно шукати вихід. На цей шлях нас повинен направляти приклад олійножирової галузі нашої країни.

Вихід лежить в площині розробки та впроваджені передових та новітніх технологій переробки зерна, які б давали можливість максимально використовувати багатий біологічний склад зернових культур.

Продаючи зернові культури як сировину ми не завжди задумуємося про біологічний потенціал який несуть в собі вони.

Корисно розглянути також фракційний склад білків основних зернових культур (табл. 6).

Аналізуючи біологічні можливості зернових культур можна окреслити цілий ряд інноваційних напрямків розвитку існуючих технологій переробки зернових культур.

Почнемо $з$ такої фундаментальної культури як пшениця та переробка її в борошно.

Для забезпечення необхідної якості кінцевої продукції традиційна технологія направлена па створення помольних партій зерна. Ідеологія такої технології базується на створенні помольних партій на базі високоякісної пшениці. І такої пшениці в помольній партії левова частка. При відсутності пшениці з високими мукомельними характеристиками отримати якісний кінцевий продукт - борошно, неможливо.

Нами пропонується змінити існуючий підхід і будувати технологічний процес шляхом переробки однорідних помольних партій зерна по технології концентрації протеїну. Це дає змогу переробляти зернові партії з невисокими мукомельними характеристиками. Реалізація такої технології можлива при використанні принципів сухого і вологого помолів та їх комбінацій. В результаті таких помолів ми будемо отримувати цілий ряд нових продуктів таких як:

- готове тісто з заданими характеристиками,

- пшеничний крохмаль,

- клейковину,

- кормові добавки.

\section{Переробка пшениці на крохмаль та інші продукти.}

При переробці пшеничного зерна для одержання крохмалю цікавим є модифікована скорочена схема при якій виділення оболонкових часток зерна вологим способом може розглядуватися як альтернатива технологічному процесу приготування борошняного тіста.
Якщо розглянутий вище процес глибокої переробки зерна обмежити етапом відділення оболонок від низькоконцентрованої крохмально-глютенової суспензії і завершити його виділенням 3 суспензії дисперсної фази, то частина процесу, що залишилась, і буде являтися альтернативою „сухого” способу одержання борошняного тіста.

Процес відділення оболонкових часток може представляти практичний інтерес в якості доповнення до випічки хлібобулочних, макаронних і кондитерських виробів. Він може займати в них ту частину, яка закінчується утворенням тістової маси для подальшої переробки.

Процес видалення оболонкових часток може доповнюватися виділенням ще і частини крохмалю.

В цьому випадку з'являється можливість регулювання складу тістової маси, в частині регулювання кількості клейковини. При використанні в якості сировини низькоякісного зерна це являється ефективним шляхом виготовлення хлібобулочних, макаронних, і кондитерських виробів прийнятної якості.

Схема технологічного процесу виділення оболонкових часток зерна і частини крохмалю (рис. 1) включає: млин-плющилку (1), чан для замочування (2), насос відцентрового або віхорного типу (3), насос (4), барабанно-струйне сито (5), шнекову осадочну центрифугу (6), чан для суспензії або відпрацьованої води (7), і спеціальну насадку-сопло (8). [ 3 ]

На переробку поступає очищене від сміття i домішок зерно. Воно проходить млин-плющилку (1), на якій виконується незначне роз плющення зерна без його подрібнення. Призначення цієї операції скорочення терміну замочування.

Після плющення зерно направляється на замочування в чан (2). Його загрузка відповідає добовій потребі підприємства. Термін замочування до однієї доби. В процесі замочування виконується промивка зерна проточною водою $з$ ціллю видалення забруднень і розчинних некорисних речовин. Витрати промивочної води до 2л/хв. В чані зерно з водою ретельно перемішується за допомогою мішалки або водяного потоку.

По закінченню замочування суспензію зерна 3 водою пропускають через насос (3) і повертають назад в чан для замочування через спеціальну насадку (8). Рух суспензії по замкнутому кільцю відбувається до тих пір, поки оболонкові частки не відділяться повністю від частинок ендосперму на них. Їх розділенню сприяє насадка (8). В ній поток прискорюється і дроселюється. 
Після достатньо повного відділення оболонок від ендосперму суспензія направляється в барабанно-струйне сито (5), в яке в одночас подається потік води. Пройшовша крізь нього мілко дисперсна суспензія води, крохмалю i глютену направляється в шнекову осадкову центрифугу (6). Частинки оболонок і частково зародок зерна сходом 3 сита направляються в відходи.

Шнекова осадкова центрифуга може працювати в двох режимах по частотам обертів ротора. В першому режимі, відповідному малим частотам (800...1500) об/хв., 3 крохмальноглютенової суспензії виділяється частина крохмалю. Величина цієї частини задається і регулюється частотою обертів ротора, а також терміном роботи в першому режимі. В цьому режимі на виході твердої фази із центрифуги виявляється вологий крохмаль, а на виході рідкої фази - крохмальо-глютенова суспензія 3 пониженим вмістом крохмалю. Вона збирається в чані (7).

Закінчення циклу виділення крохмалю визначається по його кількості, яку необхідно виділити 3 повної кількості замоченого зерна. Коли цю кількість крохмалю отримано, перший цикл роботи центрифуги закінчують, виділений крохмаль забирають, суспензію 3 підвищеним вмістом клейковини перекачують насосом (4) з чана (7) в чан для замочування (2) і приступають до другого циклу роботи.

Другий цикл відповідає підвищеній частоті обертів ротора центрифуги (3...4 тисячі об/хв.). В цьому циклі роботи на виході рідкої фракції центрифуги виявляється відпрацьована вода, на виході твердої фази - тістова маса з заданою кількістю клейковини.

Якщо виділення крохмалю з зерна не вимагається, система відразу працює в другому режимі [ 3 ].

При необхідності додаткової очистки від часток глютену виділений з зерна вологий крохмаль може бути розбавлений водою до одержання крохмального молочка і осаджений в осаджувальному чані. Після його осадження лишок води направляється в чан замочування зерна.

На сьогодні при використанні в таких процесах дво- та трьохфазних декантерів технологічна схема стає гнучкішою, вироблені продукти якісніші.

Важливо звернути увагу на економічну сутність результатів від використання інноваційних поглиблених технологій переробки зерна.

ПРИКЛАД:

Вартість однієї тони пшениці 2класу сьогодні складає - 4500гр.

3 однієї тони пшениці можна отримати:

- сухої клейковини 60кг х 85гр/кг = 5100гр

- крохмалю А $\quad 400 к г$ х 65гр/кг $=26000 г$ р

- крохмаль В 540кг х 5гр/кг = 2700гр

Разом: = 33800гр

\section{Переробка кукурудзи на крохмальну патоку,} олію та кормові добавки.

При переробці кукурудзи наша промисловість направлена на виробництво круп, борошна та використання кукурудзи в комбікормах. В кращому випадку на продовольчі цілі нинішні технології дозволяють виділяти до $60 \%$ виходу готової продукції. Все інше використовується як кормові добавки при виробництві комбікормів.

Комбінуючи технологію сухого подрібнення 3 виділенням зародку та приміняючи принципи Мартін процесу можна одержати цілий ряд важливих продуктів 3 високою доданою вартістю. Це такі продукти як кукурудзяна олія, кукурудзяний крохмаль, крохмальна патока, кормові добавки.

На рис. 3 показана принципова схема переробки супутніх продуктів круп'яного виробництва.

Економіка продуктів поглибленої переробки кукурудзяних продуктів досить чітко показує перспективність впровадження таких технологічних процесів при переробці зерна.

ПРИКЛАД:

Вартість реалізації однієї тони кукурудзи складає 3700гр

3 однієї тони кукурудзи можна отримати:

- Кукурудзяна олія 40л х 23гр/л =920гр

- Крохмальна патока 450кг х 100гр/кг = 45000гр

- Кормова добавка 510кг х 3гр/кг =1530гр

Разом: 


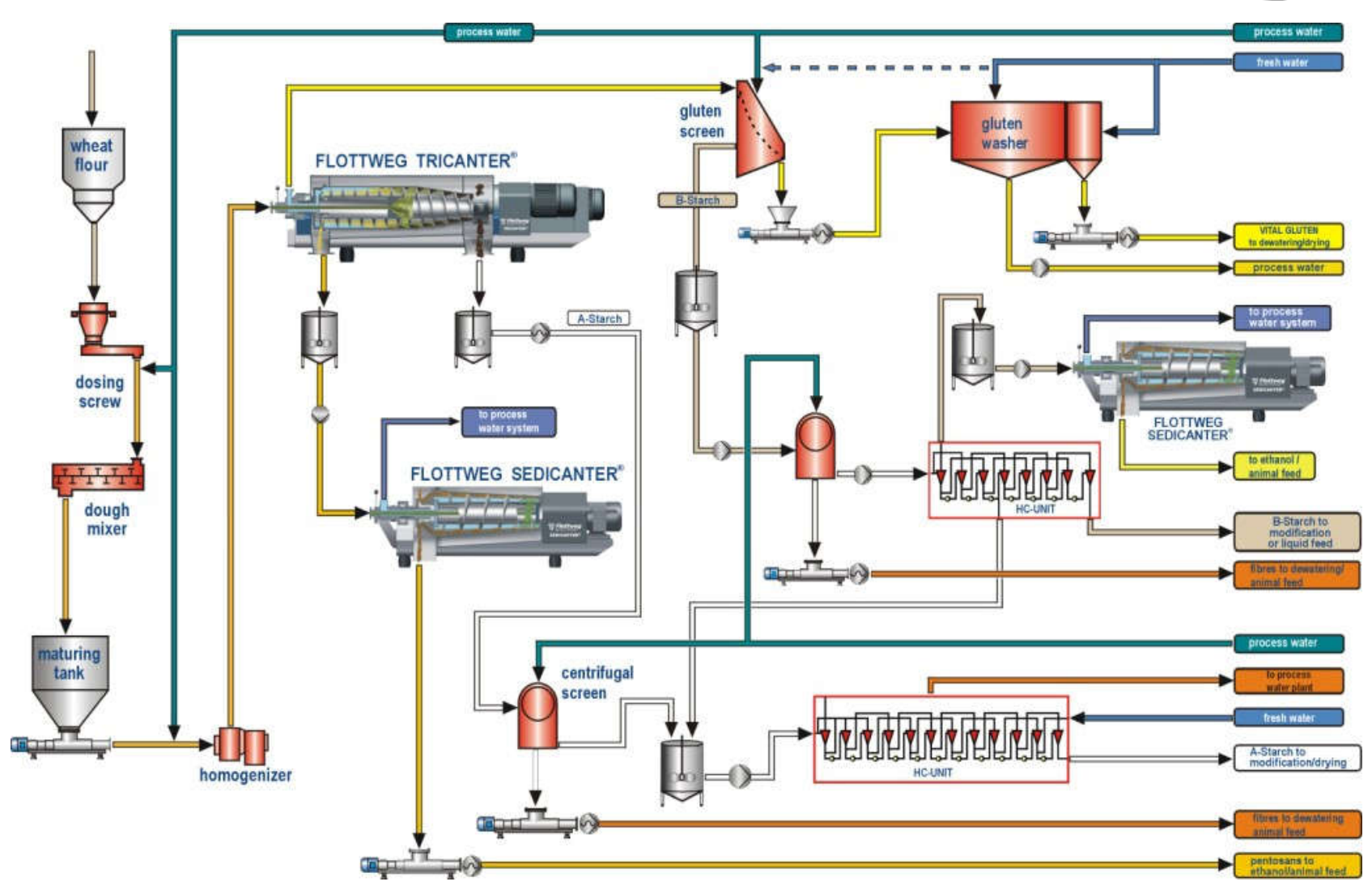

Рис. 3 - Принципова схема переробки борошна зернових культур

Ми вже згадували про проблеми які стримують розвиток комбікормової галузі. Одним із направлень комбікормових виробництв може стати виробництво лізину використовуючи супутні продукти комбікормових та зернопереробних технологій.

При виробництві цієї амінокислоти використовують штамми Corynebakterium glutamikum i Cellulomonas species.

Згідно технології, кормова амінокислота L-лізин виробляється методом мікробіологічного синтезу. Основна технологічна стадія в виробничому процесі - це ферментація, тобто культивування штамму - продуцента лізину в оптимальних умовах в спеціальних ферментерах 3 отриманням культурної рідини, вміщаючої лізин.

Проєктуєма лінія повинна забезпечувати виробничо - технологічні показники в межах: $55 \%$;

- конверсія цукрів в L-lysine $\mathrm{HCl}$ - не менше

- період збереження продуктивності штамму в безперервному процесі ферментації - не менше 400 годин;

- швидкість ферментації в перерахунку на L-lysine $\mathrm{HCl}$ не менше 2,5 грамів на годину на літр культуральної рідини;
- характеристики основного продукту $\mathrm{L}$-лізину монохлоргідрату кристалічного кормового:

- L-lysine $\mathrm{HCl}$ не менше 98,5\%;

- L-lysine не менше 78,8\%;

- волога не більше $1,5 \%$.

В якості джерела вуглеводів для харчування бактерій використовується глюкозний сироп, який необхідно виробляти на самому комбікормовому заводі з супутніх крохмальних продуктів.

Ми розглянули тільки кілька характерних прикладів можливого розвитку інноваційних технологій на підприємствах зернопереробної галузі. Їх набагато більше.

\section{Висновки}

1.Зернопереробна галузь має грунтовні перспективи для розвитку (сировинна база, можливість нарощування експорту).

2.В галузі необхідна розробка і впровадження інноваційних технологій.

3.Зернопереробна галузь повинна освоїти технології виробництва цілого ряду нетрадиційних продуктів основою яких є зерно.

4.Зернопереробна галузь України потребує кадрового забезпечення спеціалістами, які володіють новітніми технологіями.

Надійшла 13.09.2016.

До оруку 22.09.2016

Адреса для переписки: вул. Канатна, 112, м. Одеса, 65039 